Tropical Journal of Pharmaceutical Research April 2020; 19 (4): 879-885

ISSN: $1596-5996$ (print); 1596-9827 (electronic)

(C) Pharmacotherapy Group, Faculty of Pharmacy, University of Benin, Benin City, 300001 Nigeria.

Available online at http://www.tjpr.org

Original Research Article

http://dx.doi.org/10.4314/tjpr.v19i4.29

\title{
Exploring community pharmacists perception towards responsible provision of patient care services: A quantitative assessment
}

\author{
Zelal Kharaba ${ }^{1,2}$, Rozina Kousar ${ }^{3}$, Saira Azhar ${ }^{4}$, Manal Ali Buabeid ${ }^{5}$, Shujaat Ali \\ Khan $^{6}$, Ghulam Murtaza ${ }^{7 *}$ \\ ${ }^{1}$ Department of Clinical Sciences, College of Pharmacy, Al Ain University, Abu Dhabi, United Arab Emirates, ${ }^{2}$ Honorary \\ Associate Lecturer, Faculty of Medical Sciences, Newcastle University, Newcastle Upon Tyne, United Kingdom, ${ }^{3}$ Department of \\ Pharmacy, Women Institute of Learning, Abbottabad, Pakistan, ${ }^{4}$ Department of Pharmacy, University of Sargodha, Sargodha, \\ Pakistan, ${ }^{5}$ Department of Clinical Sciences, Ajman University, Ajman 346, ${ }^{6}$ Department of Pharmacy, COMSATS University \\ Islamabad, Abbottabad Campus, ${ }^{7}$ Department of Pharmacy, COMSATS University Islamabad, Lahore Campus, Pakistan
}

*For correspondence: Email: saira.azhar@uos.edu.pk, gmdogar356@gmail.com; Tel: +92-314-2082826

\begin{abstract}
Purpose: To investigate the perception of community pharmacists with regard to pharmaceutical care services in Khyber Pakhtunkhwa (KPK), Pakistan.

Methods: This was a cross-sectional survey carried out among the community pharmacists in seven divisions of KPK, namely, Bannu, Dera Ismail Khan, Hazara, Kohat, Malakand, Mardan, and Peshawar. The survey was conducted between July and September 2014. A total of 22 community pharmacists were identified and approached.

Results: Eighteen community pharmacists returned the filled questionnaire showing a response rate of $81.8 \%$. All participants $(n=18,100 \%)$ were male. The majority of the participants $55.6 \%(n=10)$ made it clear that they had never interacted with doctors, while only $33.3 \%(n=6)$ reported weekly interaction. The major reasons for interaction were to discuss drug alternatives $(38.9 \%, n=7)$ and the availability of prescribed drugs (33.3 \%, $n=6)$. Meanwhile, about $83.3 \%(n=15)$ of community pharmacists were involved in educating patients, while only $38.9 \%(n=7)$ spend enough time on each patient. Further, a large proportion of respondents had never documented patients' medical, allergy and family histories $(83.3 \%, n=15)$. Only $44.4 \%(n=8)$ of community pharmacists sometimes checked and signed the prescription.

Conclusion: Community pharmacists are few in number in the studied area. They are involved in patient counseling but face difficulties in counseling due to lack of time and insufficient pharmacy staff. Therefore, there is a need to significantly enhance the interaction between pharmacists and other healthcare professionals to facilitate inter-professional collaboration.
\end{abstract}

Keywords: Community pharmacy, Pharmaceutical care, Perception, Inter-professional collaboration

This is an Open Access article that uses a fund-ing model which does not charge readers or their institutions for access and distributed under the terms of the Creative Commons Attribution License (http://creativecommons.org/licenses/by/4.0) and the Budapest Open Access Initiative (http://www.budapestopenaccessinitiative.org/read), which permit unrestricted use, distribution, and reproduction in any medium, provided the original work is properly credited.

Tropical Journal of Pharmaceutical Research is indexed by Science Citation Index (SciSearch), Scopus, International Pharmaceutical Abstract, Chemical Abstracts, Embase, Index Copernicus, EBSCO, African Index Medicus, JournalSeek, Journal Citation Reports/Science Edition, Directory of Open Access Journals (DOAJ), African Journal Online, Bioline International, Open-J-Gate and Pharmacy Abstracts

\section{INTRODUCTION}

Pharmaceutical care practice has been found to have a significantly positive influence on patient's healthcare outcomes and disease management $[1,2]$. Thus, it requires coordination among community pharmacists and other healthcare providers along with awareness, training, and 
communication skills for the successful implementation of pharmaceutical care practice [3]. In most developing countries, the availability and proper use of medication are the major problems faced by the healthcare system. However, drug-related issues cannot be effectively managed with community pharmacists' contributions [5]. Community pharmacists are thus responsible for safe and effective medication use as they come in contact with patients regularly during their routine visits to the doctors [6].

In Pakistan, the estimated number of community pharmacies are 63,000 , while the category A pharmacists are 8102 and pharmacy technicians with categories $B$ and $C$ certifications are 31,000. Nevertheless, even if all these personnel were to be placed in community pharmacies, a large number of pharmacies will still be without community pharmacists. Currently, only $10 \%$ of pharmacists work as community pharmacists, and they are insufficient in meeting public needs. Further, most pharmacies are run by nonprofessionals and un-trained personnel [8]. Therefore, it is the duty of the Pakistan Pharmacy Council (PPC) to ensure the presence of pharmacists in all the community pharmacies to make it possible to implement the pharmacy practice and to enhance the quality of pharmaceutical care practice in Pakistan. The aim of the present study is to explore the perception of community pharmacists about the quality of pharmaceutical care services given to patients in the Khyber Pakhtunkhwa province of Pakistan.

\section{METHODS}

\section{Study design}

This was a cross-sectional study conducted among community pharmacists. A questionnaire was developed based on findings of a qualitative study conducted by the researcher in the province and after extensively reviewing the literature $[9,10]$. The questionnaire had seven sections: (a) demographic and personal information; (b) pharmacists' interaction with doctors to consult patients' prescription; (c) awareness of pharmaceutical care; (d) perception regarding patients counseling; (e) perception regarding documentation; and (f) communication with other healthcare professionals.

\section{Study population and setting}

The survey was conducted from July to September 2014 in KPK, Pakistan. The participants consisted of community pharmacists from seven major divisions (Bannu, Dera Ismail Khan, Hazara, Kohat, Malakand, Mardan, and Peshawar) of KPK, Pakistan. Before the start of the survey, ethical approval was obtained from the Departmental Research Ethical Committee. The participants were contacted and informed about the aims of this study, and verbal consent was obtained for their participation in the study. The data collection team then distributed the questionnaire to the participants.

\section{Sampling technique}

A non-probability sampling technique was adopted for the study due to the absence of a database showing the precise number of community pharmacists. Thus, a survey was first done to identify community pharmacies that lack pharmacists. Subsequently, a total of 22 community pharmacies were identified as having community pharmacists.

\section{Validity and reliability}

For the face validity of the questionnaire, the participants were selected and requested to provide their opinion regarding the importance, value, simplicity, and inclusion/exclusion of various items to make the questionnaire brief and easy for the understanding of the respondents. A reliability test was applied to all variables consisting of all domains, based on Cronbach's alpha $(\alpha=0.60)$.

\section{Statistical analysis}

The analysis of data was done by using the Statistical Package for Social Sciences (SPSS, version 20). The result of each question was reported as frequencies and percentages. The Chi-square test was applied to test the level of significance of association among the independent variables (age, gender, type of pharmacy, year of practice) and dependent variables (awareness of pharmaceutical care, perception regarding patient counseling and documentation and communication with other healthcare providers). Differences were considered statistically significant at $p<0.05$.

\section{RESULTS}

\section{Response rate}

The survey was conducted from October to December 2014. Of the 22 community pharmacists (medical stores) with a working pharmacist identified in eight major cities of seven major divisions-Bannu (01), Dera Ismail 
Khan (02), Hazara (09), Kohat (01), Mardan (01), Malakand (0) and Peshawar (04)-eighteen returned completed questionnaires showing a response rate of $81.8 \%$.

\section{Demographic profile}

Table 1: Demography and interaction of community pharmacists with doctors

\begin{tabular}{|c|c|c|c|}
\hline Variable & $\mathbf{N}(\%)$ & Variable & $\mathbf{N}(\%)$ \\
\hline Age & & Type of pharmacy & \\
\hline $20-25$ & $(11.1)^{2}$ & Independent & $(83.3)$ \\
\hline $26-30$ & $\begin{array}{r}7 \\
(38.9)^{7}\end{array}$ & Chain & $(16.7)^{3}$ \\
\hline $31-35$ & $\begin{array}{l}8 \\
(44.4)^{8}\end{array}$ & $\begin{array}{l}\text { Interaction with } \\
\text { doctors }\end{array}$ & $(\%)^{, N}$ \\
\hline $36-40$ & $(5.6)^{1}$ & Never & $\begin{array}{r}10 \\
(55.6)\end{array}$ \\
\hline Gender & & Once a week & $(33.3)^{6}$ \\
\hline Male & $\begin{array}{r}18 \\
(100.0)\end{array}$ & Once a day/more & $(11.1)^{2}$ \\
\hline $\begin{array}{l}\text { Female } \\
\text { Year of } \\
\text { practice }\end{array}$ & $0(0.0)$ & $\begin{array}{l}\text { Reason for interactions } \\
\text { Drug availability }\end{array}$ & $\begin{array}{r}6 \\
(33.3)^{6}\end{array}$ \\
\hline$<1$ & $2(11.1)$ & Side effects & $(11.1)^{2}$ \\
\hline $1-5$ & $\begin{array}{c}11 \\
(61.1)\end{array}$ & Drug alternative & $\begin{array}{r}7 \\
(38.9)^{7}\end{array}$ \\
\hline $6-10$ & $4(22.2)$ & Drug dosage & $(22 .)^{4}$ \\
\hline $11-15$ & $1(5.6)$ & Drug interactions & $(5.6)^{1}$ \\
\hline
\end{tabular}

The respondents' responses towards their interaction with doctors are summarized in Table 1. The majority of the participants $(55.6 \% ; n=$ 10) stated that they had never interacted with doctors, and only $33.3 \%(n=6)$ reported having weekly interactions with doctors. From the remaining participants (who had interactions with doctors), $38.9 \%(n=7)$ had interacted with the doctors for queries regarding drug alternatives and $33.3 \%(n=6)$ for drug availability.

The responses of the community pharmacists regarding their awareness of pharmaceutical care are summarized in Table 2. When they were asked about pharmaceutical care provision, $38.9 \%(n=7)$ of community pharmacists reported that they were sometimes provided pharmaceutical care and made efforts to improve their patients' outcomes, which was statistically significant with respect to the respondent's age $(p=0.044)$ and type of pharmacy $(p=0.027)$. More than half of the participants $(55.6 \%, n=10)$ sometimes inquired after patient's satisfaction to evaluate their work. Most of them sometimes participated in higher education programs to improve their knowledge and competence $44.4 \%$
The demographic profile of respondents is given in Table 1. All of the participants $(100 \% ; n=18)$ were male. Majority of the respondents (61.1\%; $n=11$ ) had a duration of experience of between $1-5$ years. $(n=8)$ and for patients $50.0 \%(n=9)$, which is significant with years of practice $(p=0.004)$.

The responses of the participants regarding patient counseling are summarized in Table 3. No statistically significant difference was found between the responses and patients' variables. Almost all of the participants, $94.4 \%(n=17)$ agreed that patients require counseling by pharmacists, and many of them $(83.3 \% ; n=15)$ were involved in educating patients. Only $38.9 \%$ $(n=7)$ spent enough time on each patient. The majority of the participants have not been instructing their patients about drug and/or food interaction $(88.9 \% ; n=16)$ and side effects of drugs $(83.3 \% ; n=15)$. However, half of the respondents have been instructing patients about the use of their medications (route of administration) (50.0\%; $\mathrm{n}=9$ ) and storage conditions $(55.6 \% ; n=10)$. Meanwhile, a large number of the study participants advised patients regarding healthy diet $(88.9 \% ; n=16)$, physical exercise $(72.2 \% ; n=13)$ and smoking cessation $(66.7 \% ; n=12)$. 
Table 2: Community pharmacists' awareness of pharmaceutical care

\begin{tabular}{|c|c|c|c|c|c|c|c|}
\hline \multirow[t]{2}{*}{ Question } & \multicolumn{5}{|c|}{ Response } & \multicolumn{2}{|c|}{$P$-value } \\
\hline & $\begin{array}{l}\text { Always, } \\
\text { N (\%) }\end{array}$ & $\begin{array}{l}\text { Often, } \\
\text { N (\%) }\end{array}$ & $\begin{array}{l}\text { Somet } \\
\text { imes } N \\
(\%)\end{array}$ & $\begin{array}{l}\text { Never } \\
\text { N (\%) }\end{array}$ & Age & $\begin{array}{c}\text { Type of } \\
\text { pharmacy }\end{array}$ & $\begin{array}{l}\text { Years of } \\
\text { practice }\end{array}$ \\
\hline $\begin{array}{l}\text { How often do you provide } \\
\text { pharmaceutical care to your } \\
\text { patients }\end{array}$ & $6(33.3)$ & $5(27.8)$ & $\begin{array}{c}7 \\
(38.9)\end{array}$ & $0(0.0)$ & $\begin{array}{c}0.40 \\
8\end{array}$ & 0.424 & 0.364 \\
\hline $\begin{array}{l}\text { How often do you try to } \\
\text { improve your patients' } \\
\text { healthcare outcomes }\end{array}$ & $5(27.8)$ & $6(33.3)$ & $\begin{array}{c}7 \\
(38.9)\end{array}$ & $0(0.0)$ & $\begin{array}{c}0.04 \\
4^{*}\end{array}$ & $0.027^{*}$ & 0.557 \\
\hline $\begin{array}{l}\text { How often do you inquire of } \\
\text { patient satisfaction with your } \\
\text { services for evaluation of your } \\
\text { work }\end{array}$ & $1(5.6)$ & $3(16.7)$ & $\begin{array}{c}10 \\
(55.6)\end{array}$ & $4(22.2)$ & $\begin{array}{c}0.39 \\
6\end{array}$ & 0.664 & 0.106 \\
\hline $\begin{array}{l}\text { How often do you participate } \\
\text { in higher education programs } \\
\text { to maintain and improve your } \\
\text { competence }\end{array}$ & $1(5.6)$ & $2(11.1)$ & $\begin{array}{c}7 \\
(38.9)\end{array}$ & $8(44.4)$ & $\begin{array}{c}0.72 \\
4\end{array}$ & 0.539 & 0.823 \\
\hline $\begin{array}{l}\text { How often do you participate } \\
\text { in organizing health } \\
\text { awareness programs for } \\
\text { patients }\end{array}$ & $1(5.6)$ & $3(16.7)$ & $\begin{array}{c}5 \\
(27.8)\end{array}$ & $9(50.0)$ & $\begin{array}{c}0.19 \\
2\end{array}$ & 0.928 & $0.004^{*}$ \\
\hline
\end{tabular}

Table 3: Community pharmacists' perception of patient counseling

\begin{tabular}{|c|c|c|c|c|c|}
\hline \multirow[b]{2}{*}{ Item } & \multicolumn{2}{|c|}{ Response } & \multicolumn{3}{|c|}{$P$-valuet } \\
\hline & $\begin{array}{l}\text { Yes } \\
N(\%)\end{array}$ & $\begin{array}{l}\text { No } \\
N(\%)\end{array}$ & Age & $\begin{array}{c}\text { Type of } \\
\text { pharmacy }\end{array}$ & $\begin{array}{l}\text { Years of } \\
\text { practice }\end{array}$ \\
\hline $\begin{array}{l}\text { Do you think that patients need } \\
\text { counselling by pharmacists }\end{array}$ & $17(94.4)$ & $1(5.6)$ & 0.645 & 0.833 & 0.879 \\
\hline $\begin{array}{l}\text { Are you involved in educating } \\
\text { patient regarding the drugs }\end{array}$ & 15 (83.3) & $3(16.7)$ & 0.308 & 0.558 & 0.484 \\
\hline $\begin{array}{l}\text { Do you spend enough time with } \\
\text { each patient }\end{array}$ & 7 (38.9) & $11(61.1)$ & 0.689 & 0.674 & 0.807 \\
\hline $\begin{array}{l}\text { Do you inform patients about drug } \\
\text { and / or food interaction }\end{array}$ & $2(11.1)$ & $16(88.9)$ & 0.253 & 0.686 & 0.292 \\
\hline $\begin{array}{l}\text { Do you instruct on how to use their } \\
\text { medications }\end{array}$ & $9(50.0)$ & $9(50.0)$ & 0.767 & 0.500 & 0.779 \\
\hline $\begin{array}{l}\text { Do you inform the patient about the } \\
\text { side effects of drugs }\end{array}$ & $3(16.7)$ & 15 (83.3) & 0.212 & 0.558 & 0.845 \\
\hline $\begin{array}{l}\text { Do you inform patient regarding } \\
\text { storage conditions of drugs }\end{array}$ & $10(55.6)$ & $8(44.4)$ & 0.458 & 0.588 & 0.830 \\
\hline $\begin{array}{l}\text { Do you inform patients why they } \\
\text { were prescribed the particular } \\
\text { medication }\end{array}$ & $5(27.8)$ & $13(72.2)$ & 0.334 & 0.350 & 0.182 \\
\hline $\begin{array}{l}\text { Have you ever given advice on } \\
\text { healthy eating }\end{array}$ & $16(88.9)$ & $2(11.1)$ & 0.927 & 0.686 & 0.753 \\
\hline $\begin{array}{l}\text { Have you ever given advice on } \\
\text { physical exercise }\end{array}$ & $13(72.2)$ & $5(27.8)$ & 0.289 & 0.650 & 0.544 \\
\hline $\begin{array}{l}\text { Have you ever given advice on } \\
\text { stopping smoking }\end{array}$ & $12(66.7)$ & $6(33.3)$ & 0.463 & 0.245 & 0.503 \\
\hline
\end{tabular}

Community pharmacists' responses to their perception regarding documentation are given in Table 4 where it can be seen that community pharmacists have poor participation in maintaining documentation. A large number of respondents have never documented patient history (medical, allergy and family) (83.3 \%; $n=$ $15)$, drug therapy problems potential and actual on written notes (83.3 \%; $n=15)$ and desired therapeutic objectives for each drug-related problem $83.3 \%(n=15)$. Only $44.4 \%(n=8)$ of participants sometimes check and sign the prescription, and $27.8 \%(n=5)$ sometimes find standard procedure in place for monitoring patients' progress, which is statistically significant with pharmacists' age $(p=0.003)$ and experience $(p=0.003)$. 
Table 4: Community pharmacists' perception of documentation

\begin{tabular}{|c|c|c|c|c|c|c|c|}
\hline \multirow[b]{2}{*}{ Item } & \multicolumn{5}{|c|}{ Response } & \multicolumn{2}{|c|}{$P$-value } \\
\hline & $\begin{array}{c}\text { Always, } \\
\text { N (\%) }\end{array}$ & $\begin{array}{l}\text { Often, } \\
N(\%)\end{array}$ & $\begin{array}{l}\text { Somet } \\
\text { imes, } \\
N(\%)\end{array}$ & $\begin{array}{l}\text { Never, } N \\
\text { (\%) }\end{array}$ & Age & $\begin{array}{c}\text { Type of } \\
\text { pharmacy }\end{array}$ & $\begin{array}{l}\text { Years of } \\
\text { practice }\end{array}$ \\
\hline $\begin{array}{l}\text { How often do you document the } \\
\text { patient's medical, allergy and family } \\
\text { history }\end{array}$ & $0(0.0)$ & $0(0.0)$ & $\begin{array}{c}3 \\
(16.7)\end{array}$ & $15(83.3)$ & $\begin{array}{c}0.06 \\
6\end{array}$ & 0.558 & 0.109 \\
\hline $\begin{array}{l}\text { How often do you check and sign } \\
\text { the prescription }\end{array}$ & $0(0.0)$ & 3 (16.7) & $\begin{array}{c}8 \\
(44.4)\end{array}$ & 7 (38.9) & $\begin{array}{c}0.46 \\
8\end{array}$ & 0.695 & 0.350 \\
\hline $\begin{array}{l}\text { How often do you find a procedure } \\
\text { in place for monitoring patient's } \\
\text { progress }\end{array}$ & $0(0.0)$ & $1(5.6)$ & $\begin{array}{c}5 \\
(27.8)\end{array}$ & $12(66.7)$ & $\begin{array}{c}0.00 \\
3^{*}\end{array}$ & 0.407 & $0.003^{*}$ \\
\hline $\begin{array}{l}\text { How often do you document drug } \\
\text { therapy problems potential \& actual } \\
\text { on written notes }\end{array}$ & $0(0.0)$ & $0(0.0)$ & $\begin{array}{c}3 \\
(16.7)\end{array}$ & $15(83.3)$ & $\begin{array}{c}0.79 \\
4\end{array}$ & 0.558 & 0.845 \\
\hline $\begin{array}{l}\text { How do often do you document } \\
\text { desired therapeutic objectives for } \\
\text { each drug related problems }\end{array}$ & $0(0.0)$ & $0(0.0)$ & $\begin{array}{c}3 \\
(16.7)\end{array}$ & $15(83.3)$ & $\begin{array}{c}0.79 \\
4\end{array}$ & 0.558 & 0.514 \\
\hline
\end{tabular}

* Indicates a significant difference

Table 5: Community pharmacists' communication with other healthcare providers

\begin{tabular}{|c|c|c|c|c|c|c|c|}
\hline \multirow[t]{2}{*}{ Item } & \multicolumn{5}{|c|}{ Response } & \multicolumn{2}{|c|}{$P$-value† } \\
\hline & $\begin{array}{c}\text { Strongly } \\
\text { disagree, } \\
\text { N (\%) }\end{array}$ & $\begin{array}{c}\text { Disagree, } \\
N(\%)\end{array}$ & $\begin{array}{c}\text { Agree, } \\
N(\%)\end{array}$ & $\begin{array}{l}\text { Strongly } \\
\text { agree, } \\
\text { N (\%) }\end{array}$ & $\begin{array}{l}\text { Age, } \\
N(\%)\end{array}$ & $\begin{array}{c}\text { Type of } \\
\text { pharmacy, } \\
\text { N (\%) }\end{array}$ & $\begin{array}{c}\text { Years of } \\
\text { practice, } \\
N(\%)\end{array}$ \\
\hline $\begin{array}{l}\text { Do you maintain a } \\
\text { professional relationship } \\
\text { with pharmacists, doctors } \\
\text { and nurses in your } \\
\text { practice area }\end{array}$ & $4(22.2)$ & $7(38.9)$ & $\begin{array}{c}4 \\
(22.2)\end{array}$ & $3(16.7)$ & 0.782 & 0.494 & 0.763 \\
\hline $\begin{array}{l}\text { Do you discuss the } \\
\text { patient's drug therapy } \\
\text { problems with other } \\
\text { pharmacists in your } \\
\text { practice }\end{array}$ & $2(11.1)$ & $2(11.1)$ & $\begin{array}{c}9 \\
(50.0)\end{array}$ & $5(27.8)$ & 0.525 & 0.362 & 0.799 \\
\hline $\begin{array}{l}\text { Do you refer patients to } \\
\text { other pharmacists } \\
\text { whenever it is in the best } \\
\text { interest of the patient }\end{array}$ & $1(5.6)$ & $5(27.8)$ & $\begin{array}{c}8 \\
(44.4)\end{array}$ & $4(22.2)$ & 0.837 & 0.910 & 0.602 \\
\hline $\begin{array}{l}\text { Do you refer a patient to a } \\
\text { specific physician when } \\
\text { necessary }\end{array}$ & $2(11.1)$ & $2(11.1)$ & $\begin{array}{c}9 \\
(50.0)\end{array}$ & $5(27.8)$ & 0.713 & 0.792 & 0.401 \\
\hline $\begin{array}{l}\text { Do you communicate } \\
\text { patients' progress with the } \\
\text { drug therapy to their } \\
\text { physicians or care } \\
\text { providers }\end{array}$ & $9(50.0)$ & $7(38.9)$ & $\begin{array}{c}2 \\
(11.1)\end{array}$ & $0(0.0)$ & 0.205 & 0.730 & 0.509 \\
\hline
\end{tabular}

Responses of the community pharmacists regarding maintaining a professional relationship with other healthcare providers are listed in Table 5. No statistically significant difference was found between the patients' variables and responses. Only $22.2 \%(\mathrm{n}=4)$ of the community pharmacists involved in the study agreed that they maintained a professional relationship with other healthcare professionals. They also agreed that they discuss patient drug therapy problems with other pharmacists $(50.0 \% ; n=9)$ and refer patients to other pharmacists (44.4\%; $\mathrm{n}=8)$. Half of the respondents $(50.0 \% ; n=9)$ agreed that they refer a patient to specific physicians when necessary, and about half of them strongly disagreed with the idea of communicating patients' progress to drug therapy to their physicians or care providers.

\section{DISCUSSION}

Very few medical stores, community drug stores or pharmacies were found to be operating with community pharmacists on their roll. Most of the community pharmacies bought pharmacists' licenses at a very small cost but do not give them a job. In this context, Basak and colleagues reported that legally pharmacies should be 
registered by hiring a pharmacist; however, in reality, pharmacists' licenses were instead rented out [11]. Another previous Pakistani study also reported on the unavailability of pharmacists in many community pharmacies in the country [12]. The demographic profile of the respondents revealed that all the pharmacists were male, and no female community pharmacist was found. Similar findings have been reported in a previous Pakistani study [13]. The possible reasons for this could be the social and cultural barriers that women face in Pakistan. Another reason is that community pharmacists are seen as shopkeepers. This perception prevents women from working in community pharmacies [14]. Additionally, it was also found that the majority of community pharmacists were young ( $\leq 35$ years). In a previous study on community and hospital pharmacies in Malaysia, the reported age of the participants was similar [15].

The majority of community pharmacists had rare communication with medical practitioners. It was found that pharmacists were contacted once a week only to inquire about the drug stock or drug alternatives. This indicated that community pharmacists in Pakistan have limited contact with physicians. Previously, similar findings were reported in Ireland, which also indicated poor interaction between community pharmacists and physicians. This study also highlighted that the main reason for this poor interaction was the lack of awareness [16]. The doctors had little knowledge about the professional skills and training of community pharmacists, which led to non-appreciation of community pharmacists' contributions. These findings are further supported by a previous study conducted in Canada and the Netherlands [17], which concluded that most doctors did not know the role of pharmacists. This resulted in limited contact between these two important categories of healthcare professionals.

The present study also found that only a few of community pharmacists frequently provided pharmaceutical care and to improve their patients' health outcomes. Furthermore, a large number of community pharmacists were never involved in educational programs. This shows that community pharmacists have little interest in improving their knowledge and clinical skills. This is in contrast with a Malaysian study [18] in which a large number of community pharmacists had shown interest in continuing education and emphasized improving patients' knowledge regarding their medical conditions.

Moreover, a study showed the significance of community pharmacy educational programs and reported that educational programs were equally important for improving the knowledge of participating pharmacists and students [19]. Another study also highlighted the importance of community pharmacy training programs and reported that these training programs are efficient tools for highlighting and resolving the issues pointed out by community pharmacists [20]. Similarly, the importance of community pharmacy education programs in the improvement of knowledge, interaction, and guidance skills of community pharmacists has also been highlighted [21]. Additionally, the afore-mentioned reports are further supported by the outcomes of a randomized controlled trial that suggested that pharmaceutical care interventions conducted by well-trained pharmacists bring statistically significant improvements in patients' outcomes [22]. In the current study, the majority of the community pharmacists agreed that patients needed guidance from pharmacists. This is accords with a previous study [23] in which the pharmacists were of the view that patients need guidance about the name of the drug, its storage, administration, side effects, and interactions.

\section{Limitations of the study}

The limitation of the study includes the fact that it was conducted in Khyber Pakhtunkhwa Province, and hence, the results of the study cannot be applied to the other three provinces of the country.

\section{CONCLUSION}

Based on these findings, community pharmacists in Pakistan are not actively involved in the delivery of pharmaceutical care services and are experiencing several barriers in their active participation in patient care, mainly due to their insufficient number. It is thus the responsibility of the pharmacy council to increase their number and ensure their availability in community pharmacies. Additionally, poor interaction was found between pharmacists and other healthcare professionals, therefore inter-professional collaboration needs enhancement. Further, prescription handling and documentation are poorly done and should be improved upon to achieve better pharmaceutical care practice.

\section{DECLARATIONS}

\section{Conflict of interest}

No conflict of interest is associated with this work. 


\section{Contribution of authors}

We declare that this work was done by the authors named in this article and all liabilities pertaining to claims relating to the content of this article will be borne by the authors.

\section{Open Access}

This is an Open Access article that uses a funding model which does not charge readers or their institutions for access and distributed under the terms of the Creative Commons Attribution License (http://creativecommons.org/licenses/by/ 4.0) and the Budapest Open Access Initiative (http://www.budapestopenaccessinitiative.org/rea d), which permit unrestricted use, distribution, and reproduction in any medium, provided the original work is properly credited.

\section{REFERENCES}

1. Koda-Kimble MA. The functions of pharmaceutical care in community practice. Int Pharm J 1993; Suppl I (7): 3637.

2. Erdogan ON, Erdogan MS, Gunay O, Erkus S, Ulus T. Community Pharmacists' Perception of their Clinical Pharmacy Service Function, A Study from Turkey. Farmac 2012; 60(5): 657-661.

3. Murtaza G, Kousar R, Azhar S, Khan SA, Mahmood Q. What Do the Hospital Pharmacists Think about the Quality of Pharmaceutical Care Services in a Pakistani Province? A Mixed Methodology Study. BioMed Res Int 2015. http://dx.doi.org/10.1155/2015/756180

4. Adepu R, Nagavi BG. General practitioners' perceptions about the extended roles of the community pharmacists in the state of Karnataka: A study. Indian J Pharm Sci 2006; 68: 36-40.

5. Hussain A, Ibrahim MIM. Qualification, knowledge and experience of dispensers working at community pharmacies in Pakistan. Pharm Prac 2011, 9(2): 93-100.

6. Toklu HZ, Akici A, Oktay U, Cali S, Sezen SF, KeyerUysal M. The pharmacy practice of community pharmacists in Turkey. Marmara Pharm J 2010; 14: 5360.

7. Ansel HC. The prescription. In: Gennaro AR, editor. Remington's Pharmaceutical Sciences. 17th edition. Mack Publishing Company 1985; 1778-1795.
8. Hussain A, Malik M, Toklu HZ. A Literature Review: Pharmaceutical Care an Evolving Role at Community Pharmacies in Pakistan. Pharmacol Pharm 2013; 4: 425-430.

9. Bryant LJM, Coster G, Gamble GD, McCormick RN. General practitioners' and pharmacists' perceptions of the role of community pharmacists in delivering clinical services. Res Soc Administr Pharm 2009; 5: 347-362.

10. Al-Akshar SA, Shamssain M, Metwaly Z. Pharmacists' perceptions of community pharmacy practice in UAE: An Overview. IOSR J Pharm 2014; 4(6): 47-56

11. Basak SC, Sathyanarayana D. Community pharmacy practice in India: past, present and future. Southern Med Rev 2009; 2: 11-14.

12. Wang C, Li Y, Azhar S, Murtaza G, Karim S, Kousar R, Tajik MI, Atif M, Ahmad S, Shi C. Exploring consumer views on the community pharmacists' professional role in developing countries about complementary medicine: A qualitative study. Latin Am J Pharm 2014; 33: 231236.

13. Hussain A, Ibrahim MIM. Qualification, knowledge and experience of dispensers working at community pharmacies in Pakistan. Pharm Pract 2011; 9: 93-100.

14. Hughes CM, Mccann S. Perceived interprofessional barriers between community pharmacists and general practitioners: a qualitative assessment. $\mathrm{Br} \mathrm{J}$ General Pract 2003; 53: 600-606.

15. Sarriff A, Gillani WS, Babiker GAR M, Usm SM. Pharmacist Perception to Importance and SelfCompetence in Pharmacy Practice. Int $\mathrm{J}$ Pharm Stud Res 2010; 1(2): 1-21.

16. Hughes, C. M. \& Mccann, S. Perceived interprofessional barriers between community pharmacists and general practitioners: a qualitative assessment. Brit $\mathrm{J}$ Gen Prac 2003; 53: 600-606.

17. Reebye RN, Avery AJ, Bosch WJHM, Aslam M, Nijholt A, Bij AVD. Exploring community pharmacists' perceptions of their professional relationships with physicians, in Canada and the Netherlands. Int J Pharm Prac 1999; 7: 149-158.

18. Rajiah K, Kaur KP, Sivarasa S, Ming L. Perception of community pharmacists towards patient counselling and continuing pharmacy education program in Kuala Lumpur and Selangor states of Malaysia. Am J Pharm Health Res 2014; 2: 48-56. 